EdITor,-As a female consultant and a member of the Joint Working Party on Flexible Training, recently convened by the Department of Health, I was delighted to see the editorial and supporting articles dealing with part time (now called flexible) training. ${ }^{1.3}$ The Joint Working Party has felt very strongly that doctors may wish to spend only part of the training period working flexibly and that flexible training opportunities must be tailored to trainees' needs.

I must correct some points of detail in the article. The quotas of manpower approvals are not determined by the Central Manpower Committee but rather by the request of individual specialties to the Joint Planning Advisory Committee at the time of the specialty review. These reviews are usually held triennially (and under certain circumstances more frequently) and the flexible training topslice adjusted in the light of demand within the specialty.

The information on obtaining funding for a part time senior registrar post given by J E Morrell and A J Roberts ${ }^{2}$ will soon be superseded. From 1 April 1993 all the costs of part time posts (at all grades) will be held by regional postgraduate deans. Although funding has been a problem for some flexible trainees in the past, these new arrangements should improve this aspect of the arrangements considerably.

The Joint Working Party on Flexible Training has been meeting to consider in detail the arrangements for part time training at senior registrar leve and the need for a formal scheme for other grades. Its report, which is expected early this year and wil be widely available, makes several recommendations which if accepted will improve the transition from full time to flexible working. One recommendation has already been implemented: the agreement by the $B M F$ and the Lancet to include a separate heading in the classified advertisement for part time posts.

Central Manpower Committee,

JOY EDELMAN

BMA

London WC1H 9JP

1 Van Someren V. Part time working and job sharing in the NHS BMY 1992;305:1377-8. (5 December.)

2 Morrell JE, Roberts AJ. Making an application for part time senior registrar training. BMF 1992;305:1411-3. (5 December.)

3 Thornicroft G, Strathdee G. Job share a consultant post. $B M$ 1992;305:1413-5. (5 December.)

\section{Architecture of cancer}

EDIToR,-Although there are inherent difficulties in condensing such a complex subject as the metalloproteinases to a form that is concise and comprehensive,' two aspects require further emphasis.

The first point is the question of the cellular source of the metalloproteinases. An increasing body of evidence suggests that the desmoplastic stroma in the vicinity of the tumour epithelial cells is responsible for the synthesis of these enzymes and not the tumour cells themselves as Jonathan Waxman and Harpreet Wasan's editorial implies. Poulsom et al have shown augmented signals for the messenger $\mathrm{RNA}$ of $72 \mathrm{kDa}$ gelatinase and tissue inhibitor of metalloproteinase 2 in the stroma in an in situ hybridisation study of colorecta tumours. ${ }^{2}$ Basset et al have identified a metalloproteinase gene for stromelysin 3 which at the level of messenger RNA is localised to the stroma.

Collagenases are products of fibroblasts and are up regulated in tumour stromal cells. ${ }^{+}$Studies performed in my institution on 39 colorectal carcinomas showed a stromal localisation of stromelysin and gelatinase. Their inhibitor, tissue inhibitor of metalloproteinase 1 , was also found in the stroma but had a predominant endothelia distribution (N C Gallegos et al, personal communication).

Although the concept of tumour cells producing degradative enzymes is appealing, particularly in the light of Liotta's three step theory of invasion, it is now becoming clear that production and regulation of metalloproteinases in health is a delicate host derived balance. Biological response modifiers such as cytokines and growth factors released in peritumoral tissues, perhaps by the neoplastic cells themselves, may well be implicated in their activation. ${ }^{\circ}$ Cell-matrix interactions may also play a part through signal transduction mechanisms. Inhibition of metalloproteinases, therefore, may not itself break the autocrine loops of proliferation and destruction that are created in pathological conditions such as cancer.

Secondly, much of the evidence presented in the editorial (and this letter) is based on hypotheses derived from models of invasion and metastasis that may bear little relation to the function of metalloproteinases in vivo. Further investigations are urgently required if the "futuristic technologies" are to bear any fruit.

Department of Surgery,

A K NIGAM

Rayne Institute,

University College London,

London WC1E 6JJ

1 Waxman J, Wasan H. The architecture of cancer. BMF 1992; 305:1306-7. (28 November.)

2 Poulsom R, Pignatelli M, Stetler-Stevenson WG, Liotta LA, Wright PA, Jeffery RE, et al. Stromal expression of $72 \mathrm{kDa}$ type IV collagenase and TIMP-2 mRNAs in colorectal neotype IV collagenase and TIMP-2

Basset P, Belloca JP, Wolf C, Stoll I, Hutin P, Limacher JM, et al. A novel metalloproteinase gene specifically expressed in ct al. A novel metalloproteinase gene specifically expressed stromal cells of breast carcinomas. Nature 1990;348:699-704. Biswas C. Tumour cell stimulation of collagenase production b fibroblasts. Biochem Biophys Res Commun 1982;109:1026-34. Liotta LA. Tumour invasion and metastases-role of the extracellular matrix. Cancer Res 1986;46:1-7.

6 Okada Y, Tsuchiya H, Shimuzu H, Tomita K, Nakanishi I, Sato $\mathrm{H}$, et al. Induction and stimulation of $92 \mathrm{kDa}$ gelatinase production in osteosarcoma and fibrosarcoma cell lines by tumour necrosis factor alpha. Biochem Biophys Res Commun 1990;171:610-7.

7 Overall CM, Wrana IL, Sodek J. Independent regulation of collagenase, $72 \mathrm{kDa}$ progelatinase and metalloproteinase inhibitor expression in human fibroblasts by transforming growth factor- $\beta$. I Biol Chem 1989;264: 1860-9.

\section{Avoiding exposure to HIV and hepatitis}

EDITOR,-The guidelines of the joint working party of the Hospital Infection Society and the Surgical Infection Study Group are valuable in detailing the precautions that surgical staff should take to prevent transmission of hepatitis B and C viruses and HIV.' Yet the advice to surgeons about ways in which transmission of these viruses might be avoided during operative procedures is deficient in that it fails to mention techniques of monitoring any breaches in the integrity of the barrier between the patient and surgeon.

Several studies have shown that gloves are perforated in $12-25 \%$ of procedures, ${ }^{2-1}$ although at least one report has suggested that the failure rate of gloves is as high as $52 \%$. $^{5}$ More importantly, surgeons are aware that such a perforation has occurred in only $15-50 \%$ of cases..$^{5-7}$ The knowledge that the barrier between the patient and surgeon has remained intact throughout the procedure is arguably the best reassurance for surgeons and theatre nurses regarding protection. We believe that the development and evaluation of devices to measure this is the most practical and appropriate way of implementing the recommendation of a working party of the Royal College of Pathologists that further research should evaluate measures aimed at preventing blood contact between patients and health care workers. ${ }^{8}$

Reports have shown that even with simple technology surgeons can be warned of breaches in the barrier, with low false positive and false negative rates. ${ }^{910} \mathrm{We}$ are evaluating a more sophisticated electronic device which allows the entire theatre team at risk to be monitored with minimal inconvenience. Early results have shown that the device has a high sensitivity and specificity. We believe that the joint working party's recommendations should include the routine use of such a device for people caring for patients who are known to be positive for HIV or hepatitis B virus and for high risk patients. It could be argued that such a system is valuable in all high risk operations: it provides reassurance not only for the surgical teams but also for patients who are operated on by a surgeon in whom seroconversion subsequently occurs.

Department of Surgery,

Western General Hospital

Edinburgh EH4 2XU

I M C MACINTYRE

Health Centre,

Stranraer DG9 7HD

1 Joint Working Party of the Hospital Infection Society and the Surgical Infection Study Group. Risks to surgeons and patients from HIV and hepatitis: guidelines on precautions and management of exposure to blood or body fluids. $B M \mathcal{F}$ 1992;305:1337-43. (28 November.)

2 McLeod GG. Needlestick injuries at operations for trauma. Are surgical gloves an effective barrier? $\mathcal{f}$ Bone foint Surg $[\mathrm{Br}$ 1989;71:489-91.

3 Dodds RDA, Guy PJ, Peacock AM, Duffy SR, Barker SGE Thomas MH. Surgical glove perforation. Br f Surg 1988; 75 966-8.

4 Godin MS, Lavernia CJ, Harris JP. Occult surgical glove perforations in otolaryngology-head and neck surgery. Arch Oto Head Neck Surg 1991;117:910-3.

5 Sanders R, Fortin P, Ross E, Helfet D. Outer gloves in orthopaedic procedures. I Bone foint Surg [Am] 1990;72: 914-7.

6 Serrano CW, Wright JW, Newton ER. Surgical glove perforation in obstetrics. Obstet Gynecol 1991; 77:525-8.

7 Panililio AL, Fox DR, Edwards JR, Bell DM, Welch BA, Parrish CM, et al. Blood contacts during surgical procedures. IAMA 1991;265:1533-7.

8 Royal College of Pathologist's Working Group. HIV infection hazards of transmission to patients and health care workers during invasive surgery. London: Royal College of Pathologist's, 1992.

9 Hamer AJ. Electronic device for the detection of breaches in asepsis during surgical procedures. Br $\mathcal{F}$ Surg 1987;74:1038-9.

10 Hamer AJ. Hazards to surgeons in trauma and elective orthopaedic surgery: use of an electronic device to warn of intraoperative glove perforations. Ann $R$ Coll Surg Engl 1992;74:309-11.

EDITOR,-It is recommended that health care workers in all departments should protect the mucous membranes of their eyes from blood splashes to avoid exposure to HIV and hepatitis. In Britain surgeons and theatre staff rarely wear eye protection unless they wear glasses for their eyesight or are treating high risk patients. It is increasingly common for practitioners other than surgeons, such as general practitioners and dermatologists, to perform surgical procedures under local anaesthesia.

I have assessed the risk of eye contamination during outpatient surgical procedures performed under local anaesthesia. Over six months I recorded blood spots on the front of a single pair of eye protection glasses (Surgikos). I wore these while excising small skin lesions (for example, pigmented naevi).

Blood spots were detected after 37 of 168 procedures. They varied in number from one to 24 (mean five) spots per procedure. Occasionally, blood contamination seemed to be related to use of a unipolar diathermy. In 148 of the 168 procedures I recorded whether I used diathermy. I performed 39 procedures without diathermy, and contamination occurred in four. Contamination occurred in 26 of the 109 cases in which I used diathermy.

Only a minority of the blood spots on the glasses would have entered my eyes (the glasses were fairly large, at $16.5 \times 5 \mathrm{~cm}$ ), but my experience suggests that the eyes are at risk of contamination even in minor surgical procedures carried out under local anaesthesia, especially if diathermy is used. Minor procedures are often carried out by junior surgical trainees and, increasingly, by general practitioners and dermatologists and in accident and emergency departments. It seems advisable for practitioners 